\title{
ADIPOBIOLOGY OF STEM CELL-BASED THERAPY: SECRETOME INSIGHT
}

\author{
Anton B. Tonchev ${ }^{1}$, Jerzy Beltowski², Marco Fiore ${ }^{3}$, Gorana Rančićt, Kanta Chechi', \\ Vladmila Bojanić5 , Dimitar D. Kostov ${ }^{6}$, and George N. Chaldakov ${ }^{1}$ \\ ${ }^{1}$ Laboratory of Cell Biology, Medical University, Varna, Bulgaria, ${ }^{2}$ Department of Pathophysiology, \\ Medical University, Lublin, Poland, ${ }^{3}$ Institute of Neurobiology and Molecular Medicine, National \\ Research Council (CNR), Rome, Italy, ${ }^{4}$ Department of Histology and Embryology, Faculty of Medicine \\ and ${ }^{5}$ Department of Pathophysiology, University of Niš, Niš, Serbia, and ${ }^{6}$ Department of Internal \\ Medicine, University St Marina Hospital, Varna, Bulgaria
}

Stem from the promise of stem cells therapeutic potential for a number of diseases, the regenerative medicine is reaching enthusiastic proportions nowadays. Current therapies include drug treatment, lifestyle modification, organ transplantation, RNA interference "breakthrough technology", and stem cell-based therapy. Research on stem cells is a multiplex challenge provoking both the attention and the confusion of biologists, biotechnologists, medical specialists, and politicians. By integrating various approaches of transcriptomics, proteomics and metabolomics, current adipobiology has identified more than 100 secretory proteins that are produced by the adipose tissue. These proteins designated adipokines include growth factors, cytokines, chemokines, neuropeptides and hypothalamic hormones/releasing factors. In addition, the adipose tissue's secretome contains steroid hormones, free fatty acids, prostaglandins, and endocannabinoinds. Moreover, adipose tissue is the source of adipose-derived stem cells (ADSC). Current interest in the ADSC stems from their multilineage differentiation potential, and ease of derivation in larger quantities using less invasive methods, compared with other stem cell types. The possible benefits of ADSC-based therapy may be mediated via cell proliferation/differentiation and/or paracrine mechanisms. The present review, focusing on adipose tissue secretory activity, also highlights the possible implication of ADSC in the therapy of various disorders, particularly neurodegenerative diseases, myocardial infarction and stroke, along with gut and liver diseases. Biomed Rev 2010; 21: 57-63.

Key words: adipokines, adipose tissue, diseases, growth factors, secretion

Received 10 December 2010, accepted 21 December 2010.

Correspondence: Dr George N. Chaldakov, Laboratory of Cell Biology, Medical University, BG-9002 Varna, Bulgaria. Tel.: +359 52754 394, Email: chaldakov@yahoo.com 


\section{INTRODUCTION}

\section{Crohn's disease: a prototype of adipose tissue-related disease}

Dr Burrill B. Crohn (1884-1983) with his colleagues Leon Ginzburg and Gordon Oppenheimer published an article entitled "Regional ileitis: a new clinical entity" in 1932 (cited in 1), the disease being later coined after his name. Notably, these three authors described hypertrophy of mesenteric adipose tissue adjacent to the part of inflamed intestine. Insightfully, Mycobacterium avium paratuberculosis infection was etiologically linked to "Regional ileitis" by Crohn himself, now the story being revitalized (1). Arguably, the contribution of adipose tissue to the pathogenesis of infectious diseases is gaining attention. For instance, adipose tissue is one of the major hosts of Trypanosoma cruzi infection in Chagas disease (2) and of Mycobacterium tuberculosis (3).

The present article attempts to review current concepts of adipose-derived stem cells (ADSC), focusing on adipose tissue secretory activity, particularly its paracrine phenotype. We also highlight the possible implication of ADSC in the therapy of various disorders, particularly neurodegenerative diseases, myocardial infarction and stroke, along with gut and liver diseases.

\section{ADIPOSE TISSUE}

At structural and functional level, white and brown adipose tissue (WAT and BAT, respectively) are traditionally distinguished. Although the function and topology of BAT have been re-evaluated recently $(4,5)$, adipose tissue ("WAT" will be assumed from hereon) is generally partitioned into two main large depots with visceral and subcutaneous location, and many small depots associated with various organs including heart, blood vessels, lymph nodes, eyes as well as parasellar region in the brain and epidural space in the spinal cord. Adipose tissue is a dynamic system, consisting of adipocytes and non-adipocyte cellular elements, including stromal, vascular, nerve and immune cells. These cells may input, process, and output information, a sophisticated biological module resembling brain, particularly hypothalamus (6-8).

At birth, the average-size infant has approximately five billion adipocytes, whereas their total number becomes approximately 80 billion in adults. Adding more than billion fibroblasts, mast cells, lymphocytes, dendritic cells and macrophages makes the whole body adipose tissue a major secretory organ of humans. Adipose tissue modulates whole body metabolism by controlling insulin sensitivity and circulating glucose and fatty acid levels in tissues such as muscle, liver and brain (8-15).

The most momentous challenge that has occurred in the field of adipose tissue research has been the discovery of leptin (from Greek leptos, meaning thin), an adipocyte-secreted $O b$ gene-encoded protein, in the end of 1994 (8). This became an acute trigger for the current development of adipobiology, particularly for the studies on cell protein secretion in adipose tissue $(10,13-15)$. Hence the current paradigm framed by the two Nobel Prize winners George Palade and Günder Blobel regarding the rough endoplasmic reticulumGolgi complex secretory pathway and the signal hypothesis, respectively, began to be explored in adipose tissue secretion, demonstrating that not only adipocytes but also other adipose cell types express a high secretory phenotype (9-16). For instance, 259 proteins were identified in the cultured human visceral adipose tissue 108 of them being secretory proteins (14), that is, bearing a $\mathrm{N}$-terminal secretion signal peptide. Likewise, another in-depth proteome study on 3T3-L1 adipocytes identified 3287 proteins (11), at present the largest proteome map of adipocytes.

According to current cell biology understanding, the process of protein secretion is mediated by synthesis, posttranslational modification and folding (in the lumen of rough endoplasmic reticulum), sorting and targeting to final destinations such as plasma membrane, nucleus, intracellular organelles, and exocytosis. Briefly, the three major types of secretory proteins are plasmalemmal, intracellular (imported) and exported proteins (reviewed in 13,15,17), the adipokines being an example of the latter class of secretory proteins.

Further, non-rough endoplasmic reticulum-Golgi complex pathways using multivesicular endosome-derived exosomes and plasmalemma-shedding microparticles termed ectosomes are also appreciated in recent studies on adipo-secretion $(15,16,18)$. Hence, both exosomes and ectosomes should also be considered the constituents of adipocyte secretome. Importantly, through endocrine and paracrine pathways these nano-sized structures translocate several membranes, cytosolic and nuclear proteins as well as adiponectin, exosomes being recently coined "adiposomes" (18).

In effect, systems adipobiology approach with integrated transcriptomics, proteomics and metabolomics identified more than 100 secretory (endocrine and paracrine) proteins designated adipokines (9-15). Trayhurn and Wood (10) conceptualized the proteome of adipose tissue as adipokinome, 
whereas the whole spectrum of adipose secretory products was designated secretome, the latter embodying both proteins (adipokines) and non-proteins such as free fatty acids, steroid hormones (19), endocannabinoids (20) and nitric oxide (21) among others. Using current methodologies of adipoproteomisc $(11,14,15)$, many newcomers are expected to arrive to adipose secretome.

Noteworthy, hypothalamic hormones/releasing factors, neuropeptides and neurotrophic factors are also synthesized and released from adipose tissue (6,7 and references therein) In effect, all components of adipose secretome may contribute to the regulation of numerous biological functions (appetite, satiety, energy homeostasis, lipid and glucose metabolism, inflammation, immunity, hemostasis, reproduction, aging, learning and cognition) as well as the pathogenesis of cardiometabolic $(9,12,13,22,23)$, gastrointestinal (24-27), neurodegenerative (28-31) and other diseases $(9,13)$ (Table 1).

In brief, the adipose tissue secretome is a potent producer of multiple pleiotropic factors; adipokines with a possible neuroregenerative potential are listed in Table 2. From the perspective of regenerative medicine, such a super-sized secretome may allow transplanted ADSC to exert a strong paracrine activity over the injured tissue. With the use of various bioengineering technologies, this activity may be directed in a tissue- and disease-specific manner.

\section{ADIPOSE-DERIVED STEM CELLS}

"In science, as in life, there seem to be three kinds of problems, which we classify as "easy", "difficult", or "impossible". "Easy" problems in science are those in which concept and methodology both appear to be adequate; "difficult" problems are those in which either concept and/or methodology appears to be deficient; "impossible" problems are impossible" -in 1964, the famous Oscar Hechter, together with Halkerston, wrote in their review "On the action of mammalian hormones" (32). In our present case dealing with the adipose secretome in ADSC-based therapy, the problem may be classified as a difficult, but not impossible problem.

Although the currently popular concept of stem cells can be traced back to the end of the 19th century (reviewed in 33 ), the potential of ADSC in regenerative medicine has only been appreciated recently (34-45).

Different stem cell populations have been intensively studied in the last decade as a potential source of new cells, for example, cardiomyocytes that can ameliorate the injured
Table 1. Selected list of diseases and ADSC-based therapy

\author{
Cardiometabolic diseases \\ Myocardial infarction \\ Stroke \\ Diabetes mellitus
}

\section{Neurodegenerative diseases \\ Alzheimer's disease \\ Parkinson's disease \\ Huntington's disease \\ Multiple sclerosis \\ Peripheral nerve injuries}

\section{Gut and liver diseases}

Crohn's diseases

Liver cirrhosis

Perianal fistula

\section{Others}

Rheumatoid arthritis

Erectile dysfunction

Soft tissue injuries

Chronic joint diseases

Duchenne muscular dystrophy

Table 2. Selected list of "neuroregenerative" adipokines*

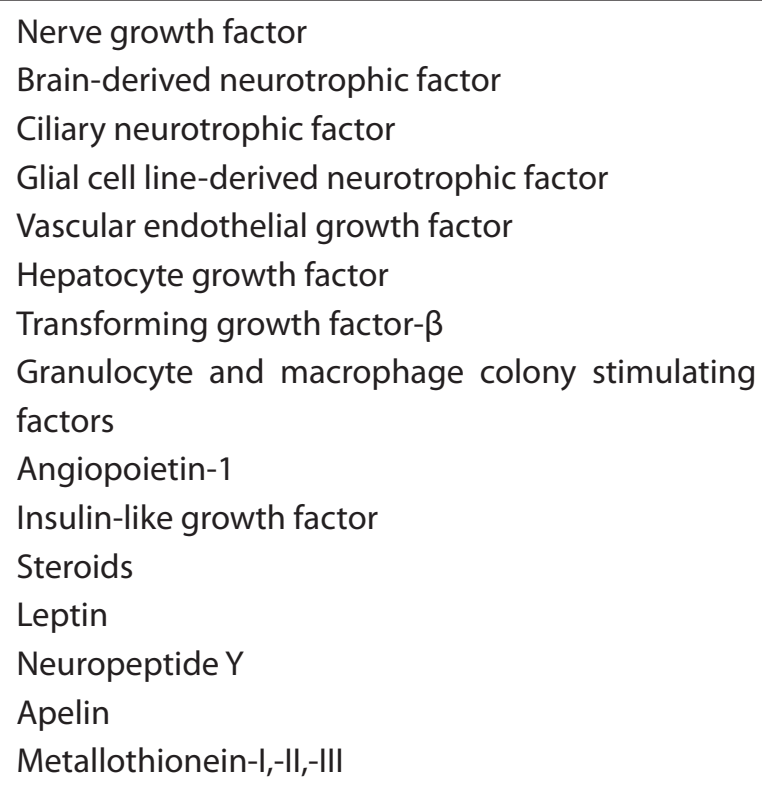

${ }^{*}$ For references $(6,7,66,68-70)$. 
myocardium and eventually restore cardiac contractility, neural cells that can rescue injured brain and peripheral nerves.

Stem cells can generally be classified into embryonic and adult form; a variation of the former is so-called induced pluripotent stem (iPS) cells, whereas bone marrow-, umbilical cord- and placenta-derived stem cells as well as ADSC and skin progenitor cells are examples of adult stem cells. For a long time, embryonic stem cells were thought to be the only source of pluripotency, a dogma that has been challenged during the last decade. The derivation of human stem cells from pre-implantation embryos (specifically, from the inner cell mass of the human blastocyst at day 5 or 6 of the early embryo development) raised great expectations for their use in regenerative therapy (33). However, ethical concerns, teratocarcinomas formation upon transplantation and immunological risks became serious limitations at the clinical settings. A feasible alternative option might be provided by auto-transplantation of ADSC or skin-derived precursor cells as easily accessible and ethically acceptable source of stem cells.

The stromal vascular fraction of adipose tissue contains stem cells, T-lymphocytes, anti-inflammatory macrophages, endothelial precursor cells, and preadipocytes. In cell culture conditions, ADSC display an impressive developmental plasticity, including a multilineage differentiation potential; they can differentiate into bone, cartilage, muscle and neuronal cells (46-55). In addition, the ADSC are capable of expressing cholinergic molecules which could be a great news for reducing the burden of Alzheimer's disease (41). Noteworthy, a subset of adipocytes may originate from the neural crest cells $(46,47)$.

Adipose-derived stem cells can be obtained by a less invasive method and in larger quantities compared with bone marrow-derived stem cells and neural stem cells. By liposuction, a common surgical operation, adipose tissue can be harvested in large quantities with minimal side effects from several regions of the body. On average, $100 \mathrm{ml}$ of human adipose tissue yields about $1 \times 10^{6}$ stem cells, or about $5 \times$ $10^{5}$ stem cells could be obtained from 400 to $600 \mathrm{mg}$ adipose tissue $(35,36,43)$. Also, the flow cytometry analysis has previously reported that ADSC express high levels of stem cellrelated antigens (CD13, CD29, CD44, CD105, and CD166) and stem cell-related transcription factors.

Understanding signaling pathways that drive proliferation, transdifferentiation and secretion of ADSC is of great importance for controlling their behavior. Applying efficient cell engineering protocols including encapsulation (for example, in microspheres) of various "stem cell growth factors" released into the medium of cultured ADSC may encourage their tissue-specific differentiation potential. Understanding various approaches involving both the transduction and the pharmacology of ADSC could further boost their utility. For instance, (i) stem cells transduced with tyrosine hydroxylase and other related genes could function as biological minipumps to enhance the dopaminergic neurotransmission after grafting (56), (ii) lovastatin, a cholesterol-lowering drug (57), and berberine, a plant antioxidant (58), both prevent ischemia-induced apoptosis in mesenchymal stem cells, and (iii) valproic acid (an anticonvulsant, mood-stabilizing and anticancer drug exerting histone deacetylase inhibitory action) affects neural stem cell proliferation (59) .

\section{ADSC: AN OLD REMEDY?}

Recent evidence shows that Homo obesus $(60$, cf. 61,62) is much prone to expressing a surprisingly high number of diseased phenotypes, including those discussed herein (2431,63-65). Symbolically, if ADSC transplantation may indeed bring therapeutic effects in patients, this might be a science-based rescue of the obese humans suffering from various cardiometabolic and neurodegenerative diseases. Indeed, reminding us of similia similibus curantur (from Latin, meaning "like cures like"), a homeopathic axiom introduced by Dr Samuel Hahnemann (1755-1843) in the first edition of his book The Organon of the Healing Art.

In conclusion, considering the ease of derivation and ethical aspects, ADSC could indeed be a better source of stem cell (66) than bone marrow-derived stem cells (67). Translated into the topic of present review, this may sound as follows: adipose secretome is better secretome than bone marrow secretome. In brief, the regenerative potential of ADSC's secretome requires further investigation and appreciation.

Altogether, "the mechanisms we have proposed may be incorrect, but they can be tested; if found untenable, they can only be replaced by "better" mechanisms" - Hecther and Halkerston wrote in their 119 page-long chapter (32).

\section{ACKNOWLEDGMENTS}

We would like to thank Drs Danko Georgiev and Desislav B. Kaplamadzhiev (Kanazawa, Japan) for creative reading of the manuscript. 


\section{REFERENCES}

1. Scanu AM, Bull TJ, Cannas S, et al. Mycobacterium avium subspecies paratuberculosis infection in cases of irritable bowel syndrome and comparison with Crohn's disease and Johne's disease: common neural and immune pathogenicities. J Clin Microbiol 2007;45:3883-3890.

2. Nagajyothi F, Desruisseaux MS, Jelicks LA, et al. Perspectives on adipose tissue, Chagas disease and implications for the metabolic syndrome. Interdiscip Perspect Infect Dis 2009; July 26: in print.

3. Erol A. Visceral adipose tissue specific persistence of Mycobacterium tuberculosis may be reason for the metabolic syndrome. Med Hypotheses 2008;71:222-228.

4. Frühback $\mathrm{G}$, Becerril $\mathrm{S}$, Sáinz N, et al. BAT: a new target for human obesity? Trends Pharmacol Sci 2009; 30:387396.

5. van Marken Lichtenbelt WD, Vanhommerig JW, Smulders NM, et al. Cold-activated brown adipose tissue in healthy men. N Engl J Med 2009;360:1500-1508.

6. Chaldakov GN, Fiore M, Tonchev AB, Hristova MG, Rancic G, Aloe L. The adipose tissue as a third brain. Obesity Metab 2009; 5: 94-96.

7. Chaldakov GN, Fiore M, Tonchev AB, Aloe L. Neuroadipology: a novel component of neuroendocrinology. Cell Biol Int 2010; 34:1051-1053

8. Friedman JM. Leptin at $14 \mathrm{yr}$ of age: an ongoing story. Am J Clin Nutr 2009; 89: 973S-979S.

9. Chaldakov GN, Stankulov IS, Hristova M, Ghenev PI. Adipobiology of disease: adipokines and adipokine-targeted pharmacology. Curr Pharm Des 2003; 9:1023-1031.

10. Trayhurn P, Wood IS. Adipokines: inflammation and the pleiotropic role of white adipose tissue. Br J Nutr 2004; 92:347-355.

11. Adachi J, Kumar C, Zhang Y, Mann M. In-depth analysis of the adipocyte proteome by mass spectrometry and bioinformatics. Mol Cell Proteomics 2007; 6:1257-1273.

12. Bełtowski J. Apelin and visfatin: unique "beneficial" adipokines upregulated in obesity? Med Sci Monit 2006; 12: RA112-119.

13. Töre F, Tonchev AB, Fiore M, Tunçel N, Atanassova $P$, Aloe $\mathrm{L}$, et al. From adipose tissue protein secretion to adipopharmacology of disease. Immunol Endocr Metab Agents Med Chem 2007; 7: 149-155.

14. Alvarez-Llamas G, Szalowska E, de Vries MP, et al. Characterization of the human visceral adipose tissue secretome. Mol Cell Proteomics 2007;6:589-600.
15. Renes J, Rosenow A, Mariman E. Novel adipocyte features discovered by adipoproteomics. Adipobiology 2009;1:5-14.

16. Deng ZB, Poliakov A, Hardy RW, et al. Adipose tissue exosome-like vesicles mediate activation of macrophage-induced insulin resistance. Diabetes 2009; August 12: in print.

17. Chaldakov GN, Vankov VN. Morphological aspects of secretion in the arterial smooth muscle cell, with special reference to the Golgi complex and microtubular cytoskeleton. Atherosclerosis 1986; 61:175-192.

18. Aoki N, Jin-no $S$, Nakagawa $Y$ et al. Identification and characterization of microvesicles secreted by $3 \mathrm{~T} 3-\mathrm{L} 1$ adipocytes: redox- and hormone-dependent induction of milk fat globule-epidermal growth factor 8-associated microvesicles. Endocrinology 2007;148:38503862 .

19. Blouin K, Veilleux A, Luu-The V, Tchernof A. Androgen metabolism in adipose tissue: recent advances. Mol Cell Endocrinol 2009; 301:97-103.

20. Matias I. The EC system in the adipose tissue and endocrine pancreas. In: J-P Després, V Di Marzo, editors. Abdominal Obesity and the Endocannabinoid System. From Basic Aspects to Clinical Management of Related Cardiometabolic Risk. Informa Healthcare USA, Inc. 2009. pp 153-162.

21. Canová NK, Lincová D, Kmonícková E, et al. Nitric oxide production from rat adipocytes is modulated by beta3-adrenergic receptor agonists and is involved in a cyclic AMP-dependent lipolysis in adipocytes. Nitric Oxide 2006; 14: 200-211.

22. Beltowski J. Leptin and atherosclerosis. Atherosclerosis 2006; 189: 47-60.

23. Chaldakov GN, Tonchev AB, Fiore M, Hristova MG, Pancheva R, Rancic G, et al. Implications for the future of obesity management. In: G Frühbeck, editor. Peptides in Energy Balance and Obesity. CAB International. 2009, pp 369-389.

24. Westcott ED, Mattacks CA, Windsor AC, et al. Perinodal adipose tissue and fatty acid composition of lymphoid tissues in patients with and without Crohn's disease and their implications for the etiology and treatment of CD. Ann NY Acad Sci 2006; 1072:395-400.

25. Paul G, Schäffler A, Neumeier M, Fürst A, et al. Profiling adipocytokine secretion from creeping fat in Crohn's disease. Inflamm Bowel Dis 2006;12:471-477. 
26. Ikejima K, Okumura K, Kon K, et al. Role of adipocytokines in hepatic fibrogenesis. $J$ Gastroenterol Hepatol 2007;22 (Suppl 1):S87-92.

27. Raszeja-Wyszomirska J, Lawniczak M, Marlicz W, et al. Non-alcoholic fatty liver disease-new view. Pol Merkur Lekarski 2008;24:568-571.

28. Giordano V, Peluso G, Iannuccelli M, et al. Systemic and brain metabolic dysfunction as a new paradigm for approaching Alzheimer's dementia. Neurochem Res 2007; 32: 555-567.

29. Tezapsidis N, Johnston JM, Smith MA, et al. Leptin: a novel therapeutic strategy for Alzheimer's disease. $J$ Alzheimers Dis 2009; 16: 731-740.

30. Luchsinger JA, Gustafson DR. Adiposity and Alzheimer's disease. Curr Opin Clin Nutr Metab Care 2009; 12:15-21.

31. Phan J, Hickey MA, Zhang P, et al. Adipose tissue dysfunction tracks disease progression in two Huntington's disease mouse models. Hum Mol Genet 2009; 18: 10061016.

32. Hecther O, Halkerston IDK. On the action of mammalian hormones. In: The Hormones. Volume 5, Academic Press Inc., New York, 1964. pp 697-816.

33. Bianco P, Robey PG, Simmons PJ. Mesenchymal stem cells: revisiting history, concepts, and assays. Cell Stem Cell 2008; 2:313-319.

34. Peroni D, Scambi I, Pasini A, et al. Stem molecular signature of adipose-derived stromal cells. Exp Cell Res 2008;314:603-615.

35. Fraser JK, Wulur I, Alfonso Z, et al. Fat tissue: an underappreciated source of stem cells for biotechnology. Trends Biotechnol 2006; 24: 150-154.

36. Bunnell BA, Flaat M, Gagliardi C, et al. Adipose-derived stem cells: isolation, expansion and differentiation. Methods 2008; 45:115-120.

37. Cherubino M, Marra KG. Adipose-derived stem cells for soft tissue reconstruction. Regen Med 2009;4:109-117.

38. Ohta Y, Takenaga M, Tokura Y et al. Mature adipocytederived cells, dedifferentiated fat cells (DFAT) promote functional recovery from spinal cord injury-induced motor dysfunction in rats. Cell Transplant 2008;17:877-886.

39. Dhar S, Yoon ES, Kachgal S, et al. Long-term maintenance of neuronally differentiated human adipose tissuederived stem cells. Tissue Eng 2007; 13: 2625-2632.

40. Zvonic S, Lefevre M, Kilroy G, et al. Secretome of primary cultures of human adipose-derived stem cells: modulation of serpins by adipogenesis. Mol Cell Proteomics 2007;6:18-28.

41. Aluigi MG, Coradeghini R, Guida C, et al. Pre-adipocytes commitment to neurogenesis 1: preliminary localisation of cholinergic molecules. Cell Biol Int 2009; 33: 594-601.

42. Riordan NH, Ichim TE, Min WP, et al. Non-expanded adipose stromal vascular fraction cell therapy for multiple sclerosis. J Transl Med 2009; 7: 29.

43. Meliga E, Strem BM, Duckers HJ, Serruys PW. Adiposederived cells. Cell Transplant 2007; 16: 963-970.

44. Cai L, Johnstone BH, Cook TG, et al. IFATS collection: Human adipose tissue-derived stem cells induce angiogenesis and nerve sprouting following myocardial infarction, in conjunction with potent preservation of cardiac function. Stem Cells 2009; 27: 230-237.

45. Lee EY, Xia Y, Kim WS, et al. Hypoxia-enhanced wound-healing function of adipose-derived stem cells: increase in stem cell proliferation and up-regulation of VEGF and bFGF. Wound Repair Regen 2009;17:540547.

46. Billon N, Iannarelli P, Monteiro MC, et al. The generation of adipocytes by the neural crest. Development 2007;134:2283-2292.

47. Billon N, Monteiro MC, Dani C. Developmental origin of adipocytes: new insights into a pending question. Biol Cell 2008; 100:563-575.

48. Gonzalez-Rey E, Anderson P, González MA et al. Human adult stem cells derived from adipose tissue protect against experimental colitis and sepsis. Gut 2009;58:929939.

49. Garcia-Olmo D, Herreros D, Pascual I, et al. Expanded adipose-derived stem cells for the treatment of complex perianal fistula: a phase II clinical trial. Dis Colon Rectum 2009;52:79-86.

50. González MA, Gonzalez-Rey E, Rico L, et al. Treatment of experimental arthritis by inducing immune tolerance with human adipose-derived mesenchymal stem cells. Arthritis Rheum 2009;60:1006-1019.

51. Roccio M, Goumans MJ, Sluijter JP, Doevendans PA. Stem cell sources for cardiac regeneration. Panminerva Med 2008; 50:19-30.

52. Sanz-Ruiz R, Fernández-Santos E, Domínguez-Muñoa M, Parma R, Villa A, Fernández L, et al. Early translation of adipose-derived cell therapy for cardiovascular disease. Cell Transplant 2009; 18: 245-254. 
53. Safford KM, Rice HE. Stem cell therapy for neurologic disorders: therapeutic potential of adipose-derived stem cells. Curr Drug Targets 2005; 6:57-62.

54. Reina MA, Franco CD, López A, Dé Andrés JA, van Zundert A. Clinical implications of epidural fat in the spinal canal. A scanning electron microscopic study.Acta Anaesthesiol Belg 2009; 60:7-17.

55. Zhao L, Wei X, Ma Z, Feng D, Tu P, Johnstone BH, et al. Adipose stromal cells-conditional medium protected glutamate-induced CGNs neuronal death by BDNF. Neurosci Lett 2009; 452:238-240.

56. Cobacho N, Serrano AB, Casarejos MJ, Mena MA, Paíno CL. Use of transduced adipose tissue stromal cells as biologic minipumps to deliver levodopa for the treatment of neuropathic pain: possibilities and limitations. Cell Transplant 2009; 18:1341-1358.

57. Xu R, Chen J, Cong X, Hu S, Chen X. Lovastatin protects mesenchymal stem cells against hypoxia- and serum deprivation-induced apoptosis by activation of PI3K/Akt and ERK1/2. J Cell Biochem 2008; 103:256269.

58. Zhang W, Su X, Gao Y, et al. Berberine protects mesenchymal stem cells against hypoxia-induced apoptosis in vitro. Biol Pharm Bull 2009; 32:1335-1342.

59. Nan GX, Li M, Liao WH, et al. Effect of valproic acid on endogenous neural stem cells proliferation in rat model of spinal cord injury. Neural Regen Res 2009; 4:513-517.

60. Chaldakov GN, Fiore F, Tonchev AB, Dimitrov D, Pancheva R, Rancic G, et al. Homo obesus: A metabotrophin-deficient species. Pharmacology and nutrition insight. Curr Pharm Des 2007; 13: 2176-2179.

61. Sadan O, Shemesh N, Cohen Y, Melamed E, Offen D. Adult neurotrophic factor-secreting stem cells: a potential novel therapy for neurodegenerative diseases. Isr
Med Assoc J 2009; 11:201-204.

62. Wei X, Zhao L, Zhong J, et al. Adipose stromal cells-secreted neuroprotective media against neuronal apoptosis. Neurosci Lett 2009;462:76-79.

63. McCoy MK, Martinez TN, Ruhn KA, et al. Autologous transplants of adipose-derived adult stromal (ADAS) cells afford dopaminergic neuroprotection in a model of Parkinson's disease. Exp Neurol 2008;210:14-29.

64. Sanz-Ruiz R, Fernández-Santos E, Domínguez-Muñoa $\mathrm{M}$, et al. Early translation of adipose-derived cell therapy for cardiovascular disease. Cell Transplant 2009;18:245254.

65. Lin G, Banie L, Ning H, et al. Potential of adipose-derived stem cells for treatment of erectile dysfunction. $J$ Sex Med 2009; 6 (Suppl 3):320-327.

66. Chaldakov GN, Fiore M, Tonchev AB, Hristova MG, Nikolova V, Aloe L. Tissue with high intelligence quotient. Adipose-derived stem cells in neural regeneration. Neural Regen Res 2009; 4: 1116-1120.

67. Zhu Y, Liu T, Song K, et al. Adipose-derived stem cell: a better stem cell than BMSC. Cell Biochem Funct 2008;26:664-675.

68. Hidalgo J, Penkowa M, Espejo C, Martinez-Cáceres $\mathrm{EM}$, et al. Expression of metallothionein-I, -II, -III in Alzheimer's disease and animal models of neuroinflammation. Exp Biol Med 2006; 254: 327-332.

69. Skalnikova H, Motlik J, Gadher SJ, Kovarova H. Mapping of the secretome of primary isolates of mammalian cells, stem cells and derived cell lines. Proteomics 2010 Dec 15; in press.

70. Salgado AJ, Reis RL, Sousa NJ, Gimble JM. Adipose tissue derived stem cells secretome: soluble factors and their roles in regenerative medicine. Curr Stem Cell Res Ther 2010;5:103-110. 